\title{
«РАЗВИЛКА" 1996 ГОДА И РОССИЙСКИЕ РЕГИОНАЛЬНЫЕ ЭЛИТЫ: ГИПОТЕТИЧЕСКИЕ СЦЕНАРИИ ТРАНСФОРМАЦИИ
}

\author{
Д. Жуков, Д. Сельиер
}

Тамбовский государственный университет им. Г.Р. Державина, Тамбов, Россия

Цитирование: Жуков Д., Сельцер Д. «Развилка» 1996 года и российские региональные элиты: гипотетические сценарии трансформации // Власть и элиты. 2020. T. 7, № 1. C. 46-75.

DOI: https://doi.org/10.31119/pe.2020.7.1.3

Аннотация. Представлень альтернативные сценарии развития российских региональных административно-политических элит, сбормированные посредством системно-динамической модели. Разработанная модель реализуется в Powersim Studio. Хронологические рамки исследования - 1985-2019 гг. Для построения модели были проанализированы механизмы и каналы рекрутирования элит, а также акторы, воздействовавшие на систему элитозамещения. Сведения об объекте моделирования формализованы в виде диаграммы запасов и потоков. Модель позволяет имитировать пополнение элит выходиами из разных социальных сред и соответственно динамику состава элит. Проанализированы реалистичный, а также два контрфактических сценария, стартовавиие в 1996 г. после гипотетической отставки Б.Н. Ельцина в связи с критическим состоянием здоровья и прихода к власти иных сил. Опираясь на результаты компьютерных экспериментов, авторы показали, что ни коммунистическая "реставращия», ни форсированная "либерализация» не устранили бы объективных предпосылок и потребностей для той региональной политики, которую реализовал позднее В.В. Путин.

Ключевые слова: системно-динамическое моделирование, политология, административно-политические элитьы, регионы России, постсоветский период.

${ }^{1}$ Автор для связи. E-mail: seltser@yandex.ru. 


\section{ВВЕДЕНИЕ: ЗАДАЧИ, ОБЪЕКТ, МЕТОДЫ И ЛИТЕРАТУРА}

Исследование сфокусировано на экспериментах с системно-динамической моделью, имитирующей в виртуальной среде принципы и механизмы рекрутирования административно-политических элит регионов России в 1985-2019 гг. Задача исследования - конструирование альтернативных (контрафактических) сценариев развития элит. Такие сценарии представляют собой инструмент для выявления свойств и потенциала реально существующей системы рекрутирования, а также для изучения ее генезиса. Эксперименты позволяют изменять отдельные условия и события, воздействовавшие на поведение и эволюцию системы, оставляя все иные аспекты модели прежними. Это дает возможность рассматривать последствия тех или иных изменений (как реальных, так и гипотетических) изолированно - «при прочих равных условиях».

Н. Гильберт и коллеги описывают эвристические возможности такого подхода: «В отличие от политического экспериментирования, вычислительные модели политики могут работать... с контрфактическими предположениями... и в соответствии с ceteris paribus (допущением, что все другие условия, кроме указанных, остаются неизменными. Д.Ж., Д.С.). Используя модели политики, мы можем исследовать альтернативные решения, просто опробовав вариации параметров в модели, и экспериментировать с контекстно-зависимыми моделями с близкими, средними и далекими временными горизонтами» [Gilbert et al. 2018: 14].

Представленное исследование является эпизодом большой программы по системно-динамическому моделированию (СДМ) региональных элит. «Объект моделирования состоит из двух групп элиты (в терминологии СДМ - “запасов” или “уровней”). Во-первых, это “административная элита среднего и низшего звена" - основная масса региональных чиновников и деятелей местного самоуправления. Вовторых, это “административно-политическая элита высшего звена” лица, которые имеют возможность принимать решения по существу региональной политики (включая формирование и расходование бюджетов) или влиять на подобные решения.

Модель показывает, из каких социальных источников пополняются эти группы в течение рассматриваемого периода, как меняется состав элиты, какие факторы (усилия различных социально-политических сил, решения властных органов и пр.) влияют или могут повлиять на эти 
процессы» [Жуков и др. 2020]. Запасы (уровни) в соответствии с традицией СДМ представлены прямоугольниками на диаграмме запасов и потоков (см. рис. 1).

Модель построена на эмпирической базе, включающей в себя статистику и аналитику, описывающие динамику элит в семи российских регионах. Эти сведения были синтезированы и формализованы в виде экспертных оценок, которые послужили исходными данными для моделирования. С определенными оговорками модель можно распространить на европейскую часть России за исключением крайних северных, южных и столичных регионов. Помимо наших работ [Сельцер 2006; 2017; 2018; Сельцер, Жуков 2017; 2019], для создания модели были привлечены изыскания российских и зарубежных исследователей [Быстрова и др. 2019; 2017; Гаман-Голутвина 2012; 2006; Даугавет и др. 2016; Дука 2014; Лапина 2004; Магомедов 2000; 2018; Мохов 1998; 2000; Нечаев 2003; Федорченко 2017; Чирикова, Ледяев 2017; Чирикова и др. 2014; Ledyaev et al. 2014; Ledyaev, Chirikova 2019a; 2019b; 2017; 2020; Turovsky, Gaivoronsky 2017].

Инструментарий системно-динамического моделирования является результатом большого числа теоретических и прикладных работ [Ахременко 2009; Гараедаги 2010; Медоуз 2011; Форрестер 1978]. На основе этого весьма авторитетного и успешного инструментария в США и Европе сформировалась «аналитическая индустрия» для поддержки прогнозирования и принятия решений в государственном и корпоративном сектоpax. Имеется также опыт приложения СДМ к решению политологических проблем [Armenia et al. 2014; Axelrod 2004; Choucri et al. 2007; Sorci 2015].

Системно-динамические модели создаются и реализуются (функционируют в виртуальной среде) посредством специализированных компьютерных программ. Представленная здесь модель создана в Powersim Studio 10.

\section{ДИАГРАММА ЗАПАСОВ И ПОТОКОВ}

Центральным элементом модели стала диаграмма запасов и потоков, которая показывает:

— какими «потоками» (каналами социального передвижения людей) связаны «запасы» между собой, а также с социальными резервуарами, из которых элита пополняется новобранцами;

- какие «механизмы» (институты) регулируют эти «потоки»;

- какие акторы (политические и социальные силы) влияют на функционирование «механизмов»; 
- какими информационными коннекторами связаны сами акторы, т.е. как они влияют друг на друга.

Диаграмма представлена на рисунке 1, легенда - в таблице 1. Социальные и политические смыслы диаграммы разъяснены детально в публикации [Жуков, Сельцер 2019а], а также в ряде других наших статей (см., напрмер: [Жуков, Сельцер 2019b]). Математический аппарат представлен в публикации [Жуков и др. 2020]. Модель в формате Powersim, результаты экспериментов, исходные данные (экспертные оценки) доступны на сайте Центра фрактального моделирования: http://ineternum.ru/sdm1/.

Модель является метатемпоральной: «Она сочетает несколько качественно разных исторических периодов, в течение которых действовали разные социальные и политические институты. Поэтому в модели некоторые элементы в течение некоторых периодов могут быть отключены. Например, актор “ЦК КПСС” после 1991 года не функционировал» [Жуков и др. 2020].

Единица времени (такт) в модели равен полугоду. Первый такт соответствует первой половине 1985 г., 70-й такт - второй половине 2019 г.

Таблица 1

Обозначения элементов диаграммы запасов и потоков

\begin{tabular}{|c|c|c|}
\hline $\begin{array}{l}\text { Графические } \\
\text { элементы }\end{array}$ & $\begin{array}{c}\text { Названия в данной } \\
\text { модели }\end{array}$ & $\begin{array}{c}\text { Термины, } \\
\text { принятые в СДМ }\end{array}$ \\
\hline & звенья & $\begin{array}{c}\text { запасы / уровни / переменные } \\
\text { уровней }\end{array}$ \\
\hline & потоки & потоки / материальные связи \\
\hline & $\begin{array}{c}\text { среды / социальные } \\
\text { резервуары }\end{array}$ & внешние источники \\
\hline & \multirow{2}{*}{ механизмы } & переменные темпа \\
\hline & & вспомогательные переменные \\
\hline & акторы & вспомогательные переменные \\
\hline & влияние & $\begin{array}{c}\text { коннекторы / информацион- } \\
\text { ные связи }\end{array}$ \\
\hline & ярлыки & ярлыки / псевдонимы \\
\hline
\end{tabular}




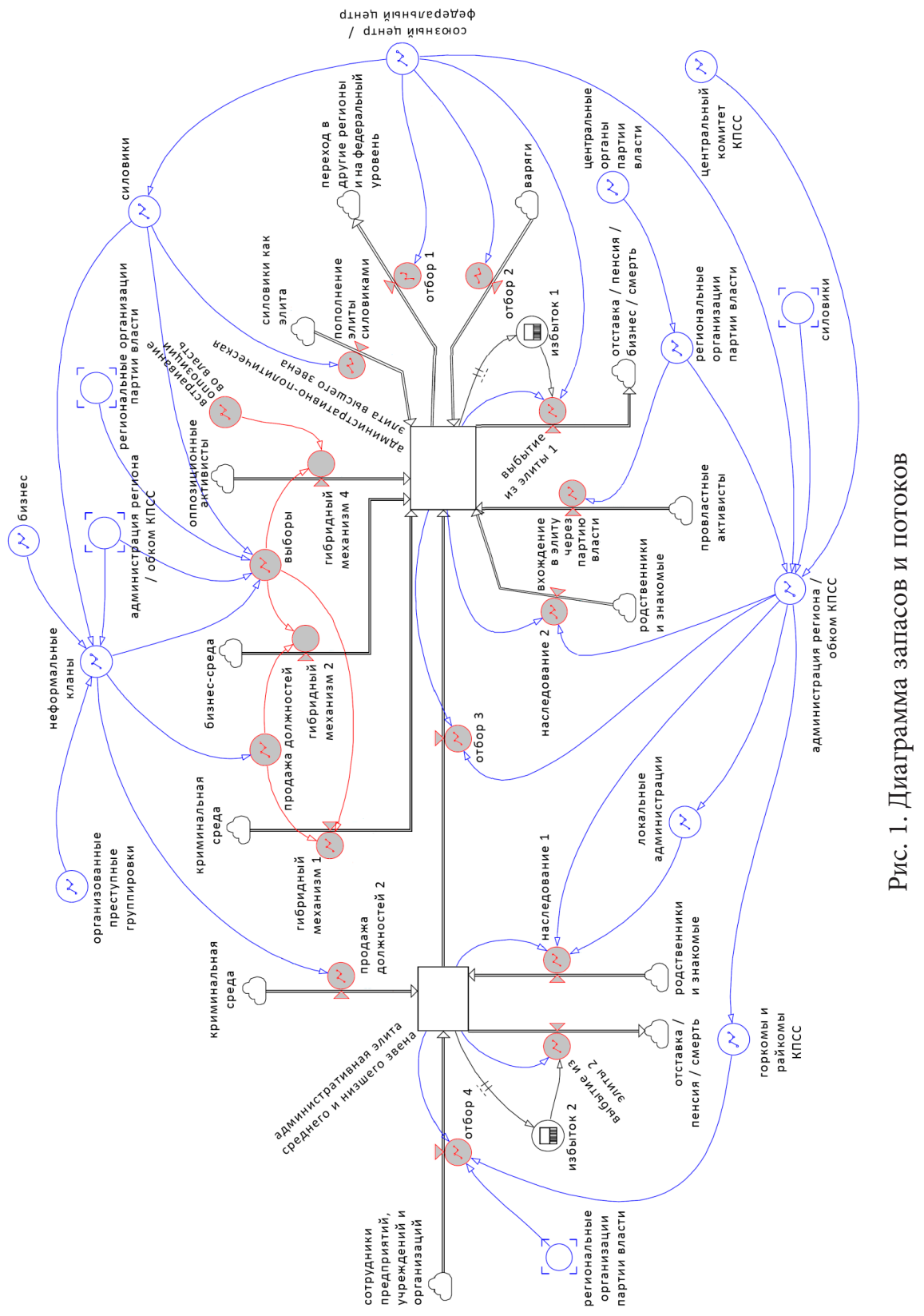




\section{РЕАЛИСТИЧНЫЙ СЦЕНАРИЙ}

Базовый сценарий имитирует свершившийся вариант развития событий и подробно описан в наших статьях (см., например: [Жуков, Сельцер 2019а]). Именно этот сценарий был использован для верификации модели посредством сопоставления результатов моделирования с известными фактами. Здесь мы отметим лишь некоторые - ключевые для данного исследования - особенности реалистичного сценария.

Рисунок 2 показывает как с некоторыми оговорками изменялся (в виртуальной среде) состав элиты высшего звена. Динамика элиты отчетливо распадается на три этапа.

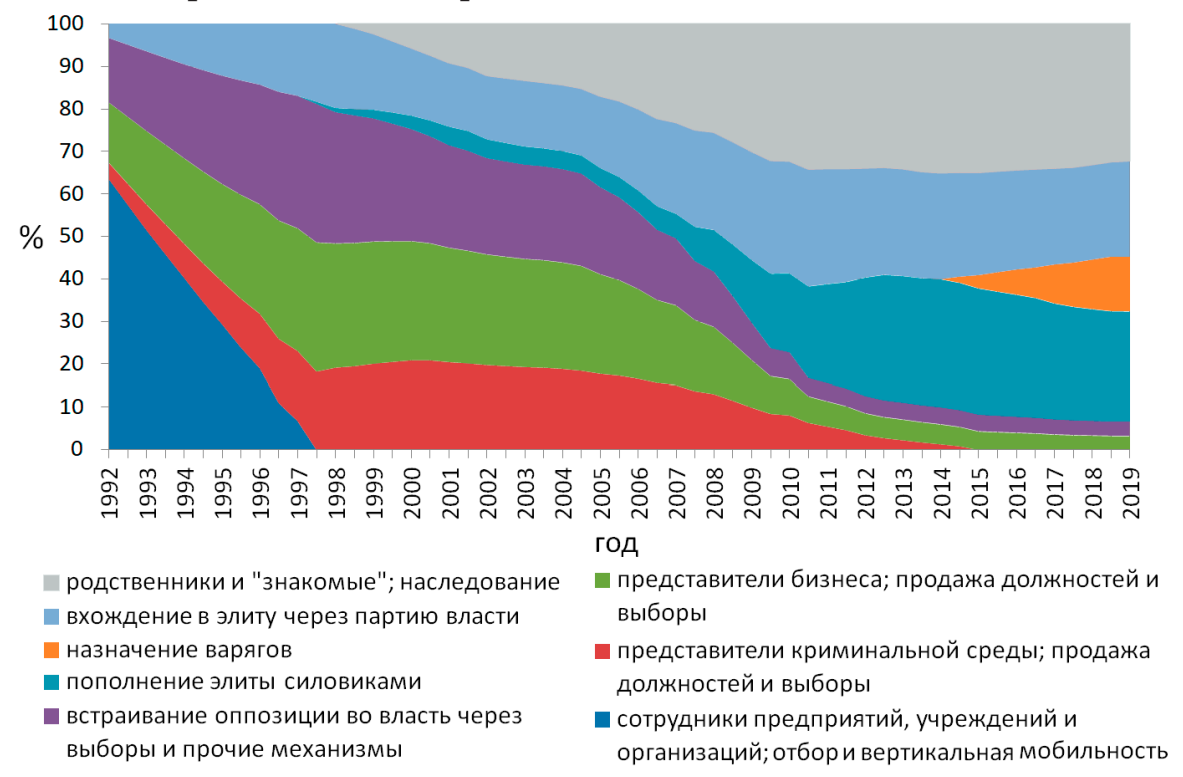

Рис. 2. Состав новобранцев в высшее звено элиты в течение минимального периода полного обновления, реалистичный сценарий

A

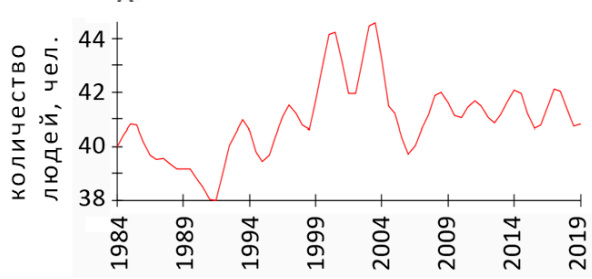

B

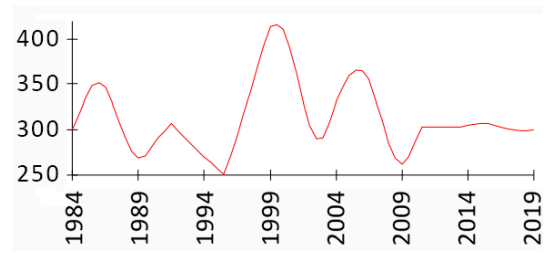

Рис. 3. Динамика численности высшего звена (А), среднего и низшего звеньев элиты (В), реалистичный сценарий 
В течение первого этапа (1991-1998) численного перевеса, а с выборов 1993-1995 гг. уже и господствующего положения внутри элиты добились группы, которые в силу своих сущностных качеств не были лояльными по отношению к федеральному центру. Это представители оппозиции, криминальной среды и бизнес-сообщества. После 1991 г. старые номенклатурные кадры были быстро вытеснены новобранцами именно из этих социальных резервуаров. К концу первого этапа федеральный центр непосредственно столкнулся с тремя системными проблемами, угрожавшими как целостности страны, так и существующей власти на федеральном уровне. Во-первых, это неуправляемость региональных элит; во-вторых, делегитимация элит и отчуждение власти и населения; в-третьих, катастрофическое падение качества элит (депрофессионализация, коррумпированность, приватизация государственных функций). Адресатом недовольства народа, как правило, становились не только и не столько регионалы, сколько федеральные властные институты, которые инициировали многие деструктивные процессы.

Содержание второго этапа (1998-2009) определялось попытками обновляющегося и, спустя время, обновленного федерального центра переломить негативные тенденции, используя наиболее доступные и быстрые инструменты. Политика выстраивания вертикали власти, проводимая новым президентом В.В. Путиным, предусматривала среди прочего препятствование (а затем и полный запрет) проникновению криминала в органы власти, а также ослабление роли выборов как механизма формирования местных элит. Это уменьшило приток в элиту бизнеса, криминала и оппозиции. Заметные результаты (в плане изменения состава элиты) такая политика начала давать к 2004 г. Если до поры численное доминирование указанных групп сохранялось (хотя и медленно убывало), то с этого момента их доля в элите начала быстро и неуклонно сокращаться.

Бизнес, криминал и оппозиция в составе элиты уступили место не только выдвиженцам партии власти, варягам и силовикам (их влияние и доля росли до 2010 г. довольно медленно), но главным образом представителям группы, которую мы обозначили как «родственники и знакомые». Это «люди, которые получили элитные позиции, постольку состояли в разного рода личных отношениях с представителями уже существующей элиты. Механизм рекрутирования таких людей мы обозначили как “наследование”. Рекрутирование элиты на основании лич- 
ных связей порождено естественным стремлением элиты как социальной группы к замыканию, наследованию и воспроизводству в поколениях своего статуса» [Жуков, Сельцер 2019а].

Такой побочный эффект чистки элит сформировал системную проблему, которая означала сохранение (конечно, в существенно меньшей мере, нежели в ельцинский период) невысокого качества элит и их низкой - мерцающей - легитимности. «Борьбой государства за оздоровление элиты в полной мере воспользовались не провластные силы, а именно традиционалистские институты, которые очень быстро возродились и отмобилизовались» [Жуков, Сельцер 2019а].

Третий этап (2009-2019) характеризовался решительным увеличением доли силовиков в региональной элите, а затем стабилизацией и консервацией текущей конфигурации сил и интересов основных региональных акторов.

Динамика низшего и среднего звена элиты представлена на рисунке 4. Очевидно, что процессы в течение первого этапа в этих звеньях можно охарактеризовать как катастрофу, а оздоровление элиты в течение второго этапа слишком затянулось и не принесло ожидаемых результатов.

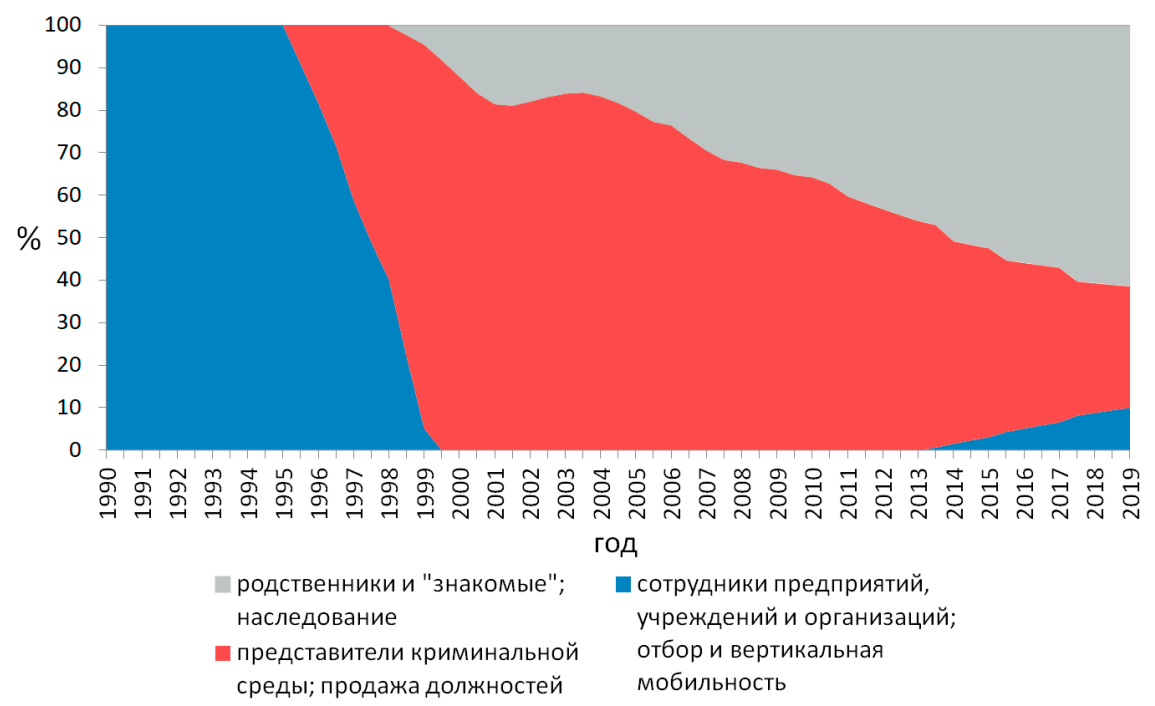

Рис. 4. Состав новобранцев в среднее и низшее звенья элиты в течение минимального периода полного обновления, реалистичный сценарий 
Пока существовали номенклатурная система и партийный контроль над расстановкой кадров, райкомы и горкомы КПСС, а также первичные партийные организации занимались рекрутированием в состав управленцев активных и способных выходцев из разных сфер - из числа так называемых «сотрудников предприятий, организаций и учреждений». После департизации фактически не осталось ни одного института, который был бы заинтересован и имел возможность поддерживать такой отбор, т.е. сохранять карьерный лифт. Управленческий аппарат поэтому быстро наполнился представителями криминала, а затем «родственниками и знакомыми». «И лишь с 2014 г. был запущен механизм отбора - в среднем звене стали появляться варяги (из числа местных деятелей, перемещенных в другие районы или другие ведомства), а в низшее звено наметился приток активной молодежи при поддержке государственных программ карьерного роста и мобильности. Однако эти механизмы пока не успели насытить элиту активными и талантливыми выходцами из других социальных сред» [Жуков, Сельцер 2019a].

\section{ПОДХОДЫ К КОНСТРУИРОВАНИЮ КОНТРФАКТИЧЕСКИХ СЦЕНАРИЕВ}

Мы рассмотрим два контрфактических сценария. Сюжеты обоих стартовали в 1996 г., когда Б.Н. Ельцин незадолго до президентских выборов ушел в отставку. В сценарии 4.2, который мы условно назвали «реставрацией», к власти в результате выборов пришли Г.А. Зюганов и КПРФ. В сценарии 4.3 - «либерализация» - выборы выиграл молодой и демократически ориентированный преемник - аналог Б.Е. Немцова (сам Б.Е. Немцов, вероятно, не смог бы сыграть эту роль, поскольку появился на федеральном уровне и стал рассматриваться как один из преемников лишь в 1997 г.). Оба сценария во вполне конкретных условиях «развилки» 1996 г., учитывая тогдашнее состояние здоровья Б.Н. Ельцина, вовсе не кажутся нам нарочито фантастическими.

В совокупности с реалистичным сценарием все три варианта представляют собой некую завершенную картину, описывающую возможные в середине - конце 1990-х годов реакции федерального центра на скоротечную деградацию региональных элит и федеративных отношений. В реалистичном сценарии для решения означенных проблем была осуществлена «вертикализация» власти с опорой на силовиков и при снижении значимости выборных процедур. 
«Реставраторы» ожидаемо сделали ставку на возрождение принципов и механизмов контроля КПСС над кадрами и кадровыми решениями. «Либерализаторы» видели главный рецепт в восстановлении доминирования партии власти в механизмах воспроизводства элиты (в логике действий «Демократической России» при формировании органов власти на рубеже 1991-1992 гг.) и в дестабилизации местных кланов посредством демократизации и хаотизации региональных политических процессов.

Оба контрфактических сценария являются инерционными в том смысле, что всецело зависят от решений, принятых в 1996 г. (или в ближайшие годы) и затем не корректировавшихся.

Необходимо обратить внимание на неявное (принятое по умолчанию), но важное условие экспериментов, сгенерировавших сценарии 4.2 и 4.3. В том и в другом случае подразумевается, что принимаются иные (по сравнению с реалистичным сценарием) политические и административные решения, но сохраняется прежний вектор социально-экономического развития страны (включая капиталистическую трансформацию и, кроме всего прочего, появление бизнеса и криминала как влиятельных акторов).

И «реставраторы», и «либерализаторы», придя к власти, задействовали наиболее простые, быстрые и наиболее доступные им инструменты - политические решения, административные рычаги и изменения законодательной базы. Однако саму систему акторов и практики их взаимоотношений они не могли изменить достаточно быстро и радикально. Иначе говоря, контрфактические сценарии не подразумевают всестороннюю и радикальную перекройку социальных институтов. Конечно, открытым остается вопрос, было бы «это так», если бы власть действительно оказалась в руках Г.А. Зюганова или политика типа Б.Е. Немцова. Однако наша задача не заключается в том, чтобы создать параллельную фантастическую реальность, а в том, чтобы протестировать возможные последствия отдельных вероятностных решений. Это позволяет понять потенциал, закономерности развития и свойства вполне реальной системы рекрутирования. Кроме того, мы считаем важным вводить в эксперименты только те гипотетические условия/ решения, которые являются наиболее вероятными, т.е. наиболее простыми и имеющими аналоги в недавнем историческом прошлом. 


\section{СЦЕНАРИЙ 4.2. «РЕСТАВРАЦИЯ": УСЛОВИЯ, РЕЗУЛЬТАТЫ, ИНТЕРПРЕТАЦИИ}

В полном объеме условия сценария описаны в приложении 1. Здесь мы лишь в общих чертах обозначим те решения и реформы, которые запустили этот вариант.

Мы исходили из того, что «возрожденная КПСС» вернулась к прежним смыслам, задачам и принципам подбора и расстановки кадров как в высшем, так и в среднем и низшем звеньях региональных элит. Однако влияние Коммунистической партии на систему рекрутирования кадров снизилось приблизительно на треть даже по сравнению с 1991 г. Действительно, трудно предположить, что в 1996 г. удалось бы вернуться к уровню влияния КПСС брежневского времени.

Были восстановлены низовые партийные организации на предприятиях и в учреждениях, в кадровых вопросах восстановлен контроль обкомов/рескомов над региональными администрациями. Кроме того, во второй половине 1996 - первой половине 1997 г. была проведена чистка аппарата управления на региональном уровне: освобождено от занимаемых должностей 20 \% (от текущей численности) служащих во всех звеньях.

Эксперимент «реставрация» продлился со второй половины 1996 до 2019 г. Необходимо, однако, иметь в виду, что реальная политика «реставрации» могла быть прервана значительно раньше - через один или два президентских срока. Таким образом, 2000 и 2004 гг. следует считать в этом сценарии (равно как и в сценарии «либерализации») критически важными. Именно к этим датам должны были проявиться результаты «перелома 1996 года», определившие в значительной мере успех или неуспех того или иного сценария.

Реставрация вызвала явную колебательную динамику общей численности всех звеньев (рис. 5). Для высшего звена это не стало проблемой: здесь имели место сравнительно несильные колебания в диапазоне от 40 до 43 человек с периодом около 3-4 лет. В то же время численность среднего и низшего звеньев колебалась с периодом около 6 лет в огромном диапазоне от 241 до 445 человек.

При такой динамике низшего и среднего звеньев невозможно надеяться на формирование сколько-либо профессиональной и некоррумпированной касты бюрократов, которая могла бы стать резервуаром для рекрутирования неономеклатурщиков, на которых намеревались 

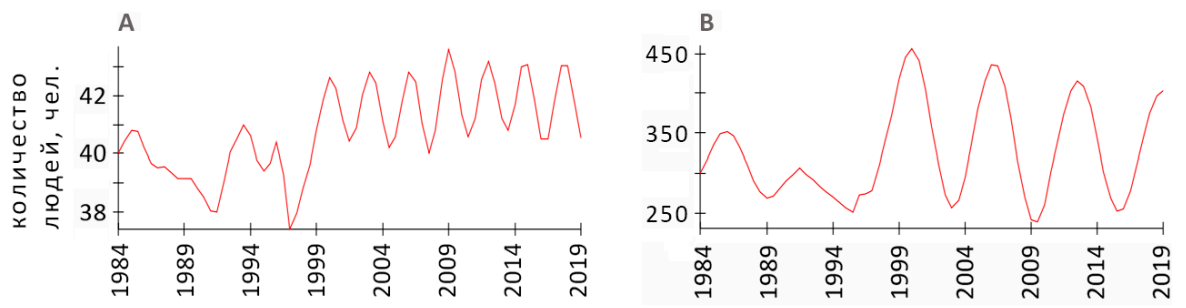

Рис. 5. Динамика численности высшего звена (А), среднего и низшего звеньев элиты (В), сценарий «реставрации»

опереться «реставраторы». Давление на механизмы рекрутирования со стороны выходцев из криминальной среды было столь велико, что каждые шесть лет система была вынуждена быстро сбрасывать численность. Однако результаты подобных чисток уже спустя три года нивелировались - и низшие звенья вновь заполнялись «сомнительными личностями». Мы видим, что сокращение (кстати, не очень большое) возможностей криминала поставлять своих людей в высшее звено, привело к захвату ими значимых позиций внизу административной иерархии.

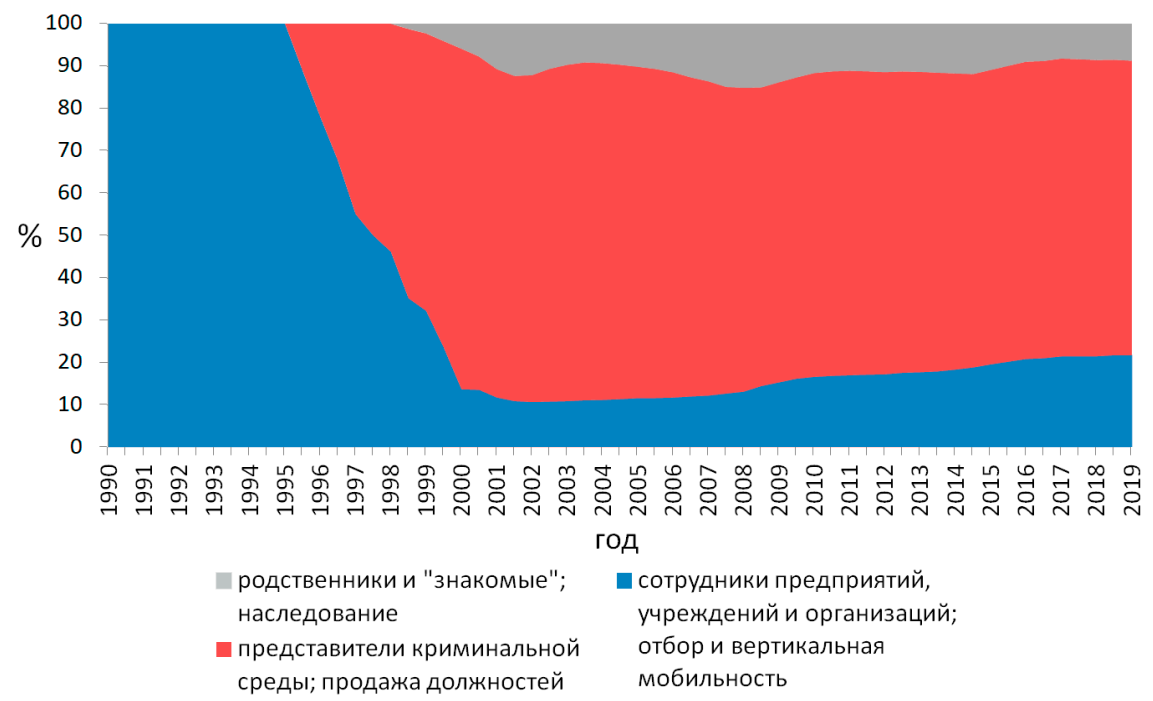

Рис. 6. Состав новобранцев в среднее и низшее звенья элиты в течение минимального периода полного обновления, сценарий «реставрации» 
На рисунке 6 заметно, что усилия «реставраторов» привлечь лояльные кадры карьерных служащих в аппарат дали результат. Однако этот результат никак не мог компенсировать общую (очень быструю) деградацию состава низшего и средних звеньев. Старые механизмы отбора не были восстановлены в полной мере, но, что самое важное, они уже не могли быть монопольными - у них появились конкурирующие механизмы, которые были поддержаны весьма влиятельными социальными силами. В итоге возникла ситуация, когда «старые кадры» (пришедшие в аппарат еще во времена СССР) в силу естественных причин вымывались, но не компенсировались «новой кровью» - талантливыми и политически активными «сотрудниками предприятий, организаций и учреждений». Общая численность этой когорты к 2001 г. достигла лишь 12 \%, а к 2019 г. - 22 \%. Это лучше, чем в реалистичном сценарии, но недостаточно и медленно, чтобы оздоравливающий эффект (который, конечно, имел место вследствие роста этой когорты) стал хорошо заметен и начал управлять динамикой элиты.

Кроме того, с представителями криминала не смогли конкурировать и «родственники и знакомые», поскольку «реставраторы» относились к этой когорте негативно и стремились не допустить ее расширения.

В целом «реставраторы» столкнулись в среднем и низшем звеньях с теми же проблемами, что и в реалистичном сценарии: низовые уровни аппарата не удалось уберечь от засилья криминала.

В высшем звене ситуация также улучшалась, но катастрофически медленно (рис. 7). Основная опора «реставраторов» - неономенклатурщики, несмотря на сильную поддержку со стороны «возрожденной КПСС», к 2001 г. достигли чуть более 14 \%, а к 2019 - 17,5 \%. Несомненно, это позитивная тенденция (по сравнению с реалистичным сценарием). Полагаем, что наличие такой когорты стабилизирует управленческий аппарат, способствует профессионализации и тормозит коррупционную деградацию. Негативной тенденцией было то, что (в отличие от реалистичного сценария) численность криминала, бизнеса и оппозиции сокращалась очень медленно. В 1996 г. упомянутые когорты имели в совокупности 66 \% позиций в элите, в 2001 г. - 75 \%, а в 2019 г. - 43 \%. Учитывая, что в альтернативной реальности доля этих когорт впервые упала ниже 50 \% лишь в 2016 г., «реставраторы» вряд ли смогли бы сохранить свою власть в регионах в каком-либо реальном смысле.

«Реставраторы» не смогли реализовать своих задач в кадровой политике - они не создали лояльного и профессионального большинства 


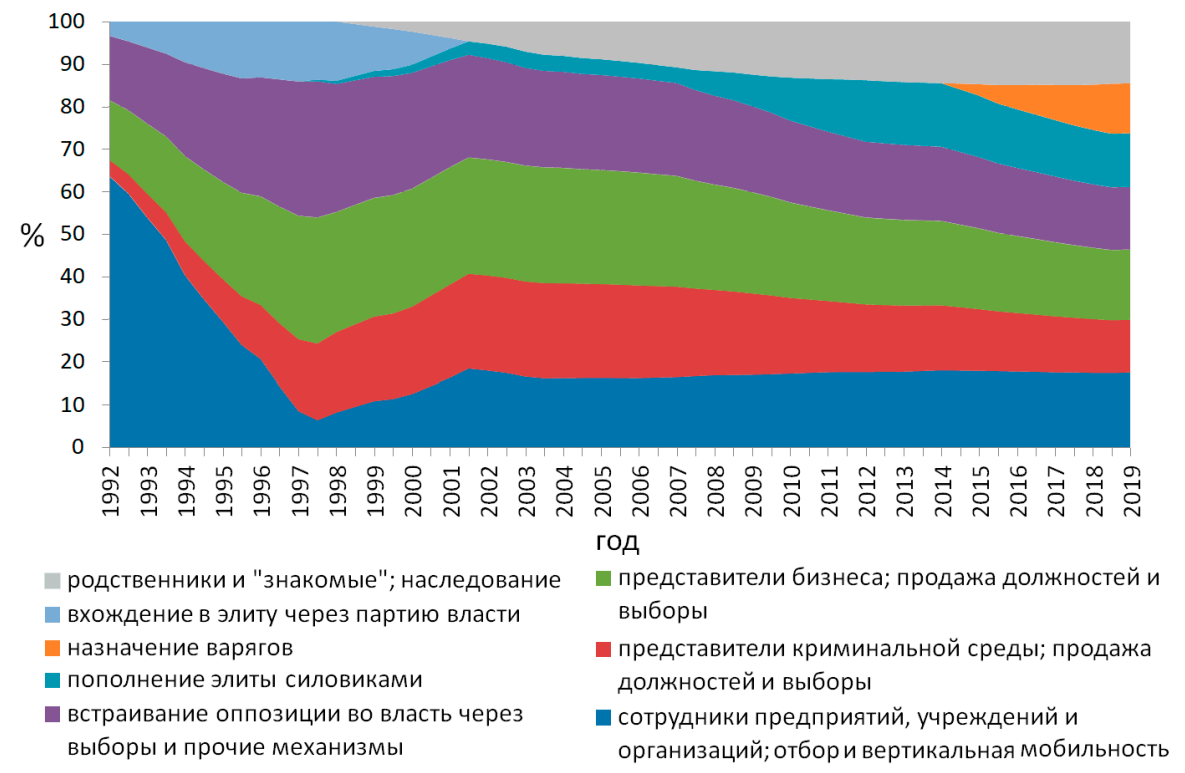

Рис. 7. Состав новобранцев в высшее звено элиты в течение минимального периода полного обновления, сценарий «реставрации»

в региональной элите. В сущности, к моменту новых выборов - в 20002001 гг. - власть столкнулась с теми же проблемами, как и в реалистичном сценарии. Политическую ситуацию «реставраторов» (в плане обеспечения контроля над элитами, повышения их качества и легитимности) можно считать катастрофической практически на протяжении всего периода — от 1996 до 2019 г. «Реставрация» не устранила объективных предпосылок и потребностей для той политики, которую реализовал В.В. Путин.

Среди удач «реставраторов» можно назвать то, что «родственники и знакомые» к 2019 г. имели в элите долю лишь 15,5 \% (это меньше, чем в реалистичном сценарии, где в это же время "родственников и знакомых» скопилось более 32 \%). Однако эта удача вряд ли способствовала политическому успеху «реставраторов». «Родственники» обычно политически комформны и неопасны для власти в кратко- и среднесрочной перспективе. Но они разрушительно воздействуют на властные институты в долгосрочной перспективе. Стремление элиты к замыканию и передаче власти по наследству напрямую ведет к дискредитации 
и делегитимации власти. Это непосредственная причина отчуждения власти и народа.

Элита эпохи «реставрации», в сущности, даже без засилья «родственников» вряд ли могла претендовать на легитимность. Многочисленные когорты криминала и бизнеса, конечно, лишали власть скольколибо значимых шансов приобрести доверие и авторитет в глазах населения. «Реставраторы» не смогли изолировать систему рекрутирования от давления новых социальных сил. Ставка на возрождение номенклатурных практик времен КПСС, казавшаяся весьма благотворной в плане оздоровления элиты (и, возможна, отчасти и бывшая таковой), была системно недостаточна, для того чтобы остановить деградацию качества элиты.

\section{СЦЕНАРИЙ 4.3. «ЛИБЕРАЛИЗАЦИЯ»: УСЛОВИЯ, РЕЗУЛЬТАТЫ, ИНТЕРПРЕТАЦИИ}

В полном объёеме условия сценария описаны в приложении 2. Здесь обратим внимание лишь на ключевые моменты политики «либерализаторов» в сфере воспроизводства региональных элит. Проблемы утраты контроля и падения качества элит «либерализаторы» должны были бы решать исходя из собственных теоретических представлений и своего короткого исторического опыта.

Федеральный центр поэтому стремился снизить влияние силовиков и существенно повысить значимость выборов как механизмов рекрутирования элиты. Это соответствовало демократическим умонастроениям новой власти - установкам на форсированный транзит. Кроме того, такая политика рассматривалась как средство сделать механизмы рекрутирования (и в целом региональные политические процессы) более конкурными, помешав тем самым консолидации и консервации власти в руках региональных кланов и/или коммунистов-реваншистов. Заметим, что побочным эффектом такого курса стала невозможность для силовиков переориентироваться на противодействие неформальным кланам (что имело место в реалистичном сценарии с 2000-х годов).

Вторая ключевая ставка «либерализаторов» - значительное усиление новой (или обновленной) демократически ориентированной партии власти. Она должна была служить каналом, через который региональная элита насыщалась бы людьми, от которых можно было бы ожидать «верности принципам» и готовности следовать в фарватере новой обще- 
национальной политики. На первый взгляд, кажется, что выбор такого рычага воздействия на регионы нехарактерен для «либерализаторов». Однако, делая такой выбор, они копировали свой недавний и, по существу, единственный успех в региональной кадровой политике. В начале 1990-х годов первая партия власти - движение «Демократическая Россия» - смогла на короткое время сосредоточить в своих руках право определять назначения на ключевые должности в регионах. Это позволило быстро отстранить «старые кадры». Такие успехи, конечно, опирались на полномочия и авторитет еще популярного в то время Б.Н. Ельцина.

Кроме того, следует предположить, что «либерализаторы» должны были стремиться наполнить низшие и средние звенья элиты «новой кровью», т.е. запустить механизмы рекрутирования талантливых и политически лояльных новобранцев из внеэлитной среды на низовые должности в аппарате управления. Однако новая партия власти практически не имела опыта в сфере подбора низовых кадров (в отличие от «возрожденной КПСС»). Кроме того, эта деятельность требует создания разветвленной партийной структуры «на местах». Поэтому мы установим, что механизмы отбора и рекрутирования были запущены лишь с 1997 г.

Графики на рисунке 8 показывают общую динамику численности разных звеньев элиты. Оба графика свидетельствуют о невиданной борьбе за власть.

В низшем и среднем звеньях (рис. 8А) численность элиты колебалась с периодом около шести лет в диапазоне от 250 до 440 человек. Эта динамика очень похожа на сценарий «реставрации». Размах и частота колебаний не оставляют никаких шансов для формирования нормального (т.е. лояльного, малокоррумпированного и профессионального)
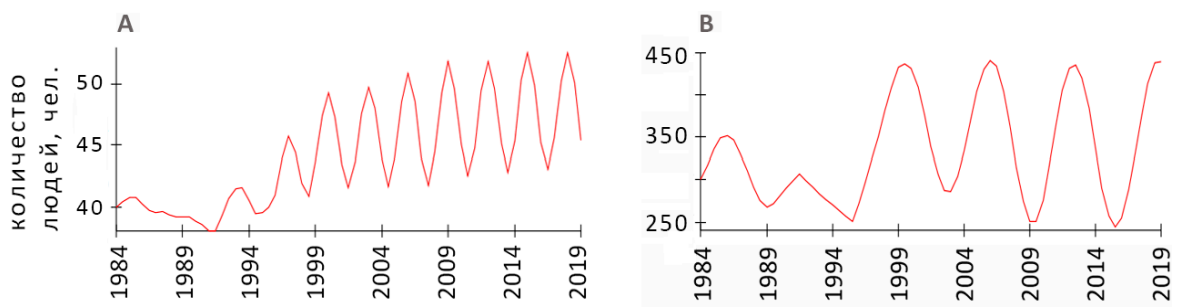

Рис. 8. Динамика численности высшего звена (A), среднего и низшего звеньев элиты (В), сценарий «либерализации» 


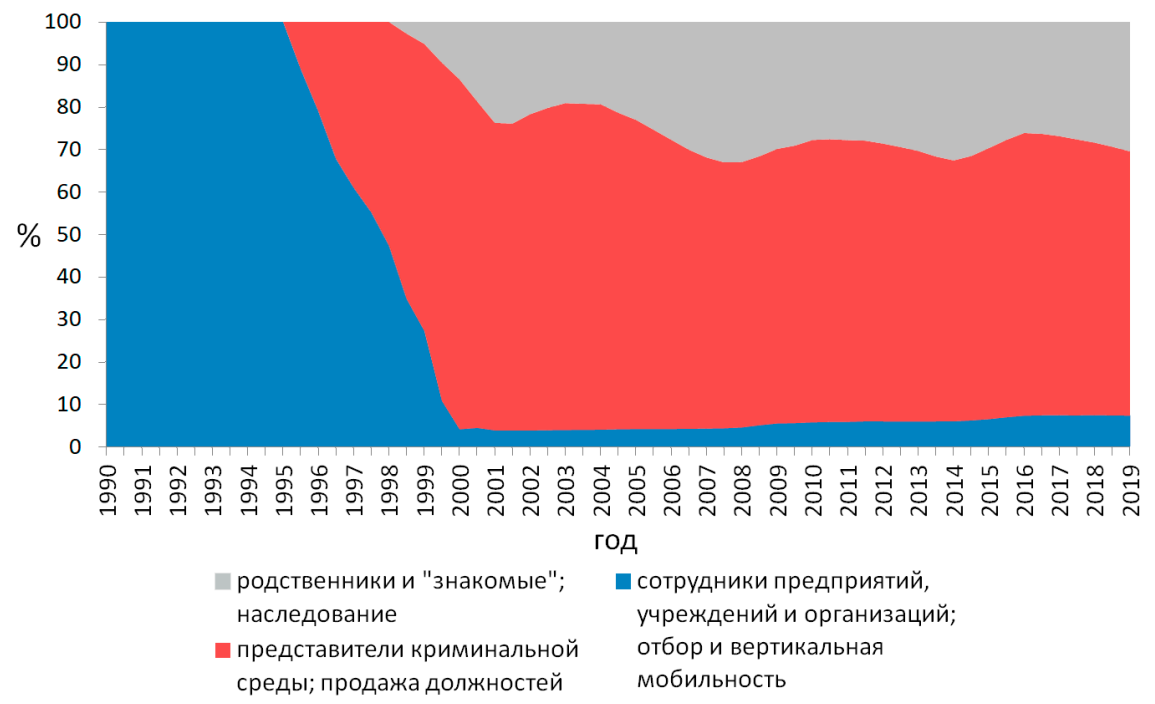

Рис. 9. Состав новобранцев в среднее и низшее звенья элиты в течение минимального периода полного обновления, сценарий «либерализации»

аппарата. Поход криминала во власть (в данном случае в ее нижние уровни) провоцирует регулярные чистки (сбросы численности), которые, однако ничего не меняют в самой системе, открытой для подобного рода давления. В результате довольно быстро цикл повторяется.

Если в сценарии «реставрации» колебания высшего звена (см. рис. 3А) были незначительны, то в сценарии «либерализации» колебания высшего звена (рис. 8В) крайне болезненны: с периодичностью около 3-4 лет численность колеблется в диапазоне от 44 до 53 человек (т.е. $\pm 22,5 \%$ от оптимальной численности). Более того, колебания не имеют тенденции к затуханию. Это следует рассматривать как свидетельство регулярного переполнения элиты и несбалансированности усилий и интересов разных акторов, которые воздействовали на систему рекрутирования. Здесь не было, вероятно, сколько-либо устойчивых внутриэлитных соглашений между акторами, которые, очевидно, пребывали в постоянной и ожесточенной борьбе за власть.

Заметим, что колебательную динамику далеко не всегда можно трактовать как признак патологии (в реалистичном сценарии мы также наблюдали колебания, но не столь большого размаха и имеющие тенденцию к затуханию - см. рис. 3). Колебательная динамика свойствен- 
на многим процессам в природе, и социальным, и биологическим, и физическим. Это естественный механизм поиска и поддержания динамического баланса, реагирования на внешние импульсы. Однако, конечно, незатухающие сильные колебания не следует рассматривать в данном примере как нормальное состояние дел.

Успехи «либерализаторов» в оздоровлении низшего и среднего звеньев можно назвать столь же скромными, как и достижения «реставраторов» (рис. 9).

Пополнение управленческого аппарата талантливой молодежью из других сфер нисколько не компенсировало выбытие «старых кадров». К 2001 г. вертикальными социальными лифтами смогло воспользоваться лишь 4,4 \% от общего числа человек в среднем и низшим звеньях, а в 2019 г. - 7,3 \%. Конечно, новоявленные механизмы рекрутирования, которые попытались создать «либерализаторы», оказались слабее, чем старые механизмы расстановки кадров, функционировавшие под эгидой «возрожденной КПСС». Кроме того, существенную долю смогли отвоевать для себя «родственники и знакомые». Доминирование криминальной среды и в этом сценарии неоспоримо и не имеет заметной тенденции к сокращению.

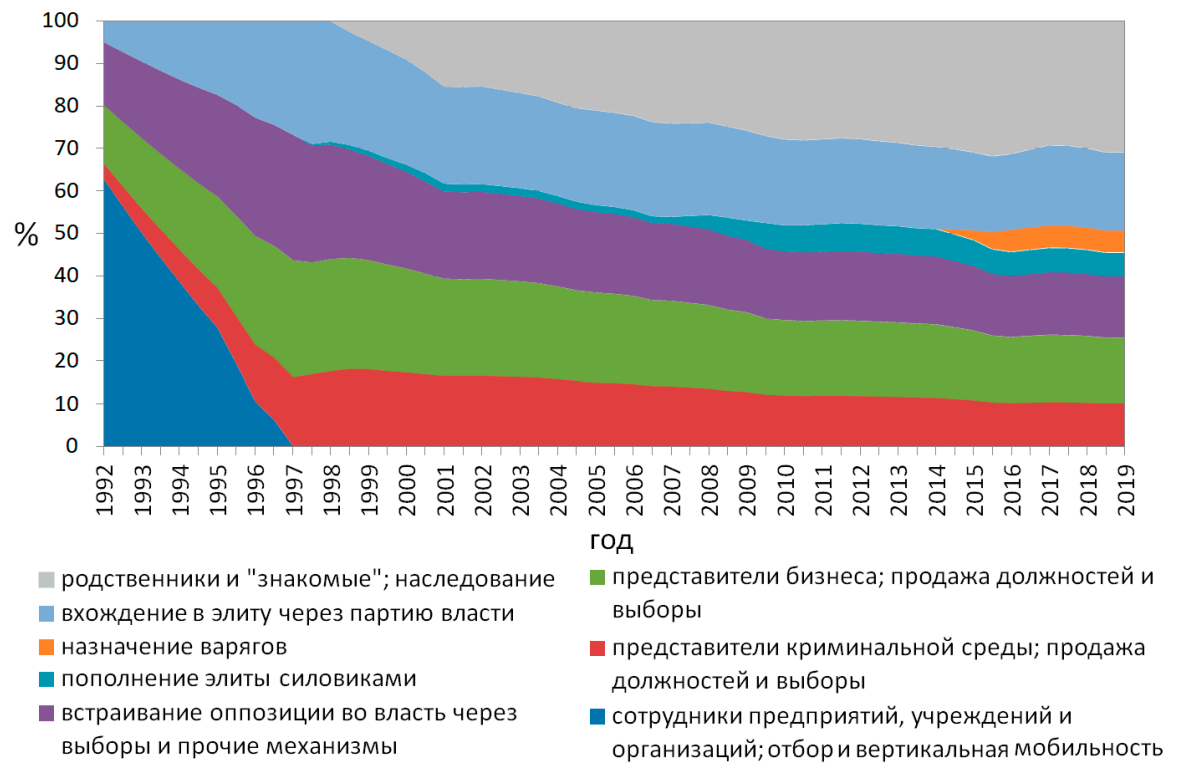

Рис. 10. Состав новобранцев в высшее звено элиты в течение минимального периода полного обновления, сценарий «либерализации» 
Анализ динамики состава высшего звена (рис. 10) показывает, что своих основных целей «либерализаторы» не достигли. Хотя они и создали для себя политическую ситуацию (в плане контроля над региональными элитами), несколько лучшую, чем «реставраторы», тем не менее их положение и к 2001, и к 2019 г. можно считать очень близким к катастрофическому.

Основная опора «либерализаторов» - успешные и лояльные представители демократически ориентированной партии власти. Накануне победы «либерализаторов» партия власти имела почти 23 \% позиций в высшем звене. Немалые усилия «либерализаторов» по расширению доли новой (или обновленной) партии власти дали наибольшую отдачу к 1998 г., когда эта доля превысила 28 \%. Далее доля «демпартийцев» в элите медленно падала до 23 \% к 2001 г. и до 18,4 \% - к 2019 г. Конечно, «либерализаторам» удалось сформировать большую и лояльную когорту в элите, но доминирования она определенно не достигла.

«Либерализацией» в полной мере воспользовались «родственники и знакомые», которые в большей мере, нежели остальные претенденты, расширили свое представительство (почти 31 \% к 2019 г.). «Родственники и знакомые» стали самой большой когортой элиты (в реалистичном сценарии их доля достигла к 2019 г. похожей величины - 32,3 \%).

Показательно, что доля "родственников и знакомых» демонстрировала уверенный рост при диаметрально противоположных политиках и при форсированной демократизации (сценарий «либерализации»), и при антилиберальных ограничениях (реалистичный сценарий «вертикализации власти»). Полагаем, объяснение этого эффекта заключается в том, что механизм пришествия «родственников» во власть одинаково индифферентен к тому и другому типу политики и чужд противоречиям между демократами, коммунистами или государственниками. Можно сказать, что пришествие во власть "родственников» было проявлением фундаментально иной линии эволюции, принципиально оппозиционной всем трем упомянутым стратегиям. Увеличение численности «родственников и знакомых» - это индикатор архаизации и замыкания элит, проявление регресса на очень глубоком социальном уровне. Такая тенденция не чувствительна к тому, происходит ли всемерное развитие выборных процедур или идет выстраивание вертикали власти. Истоки замыкания элит находятся вне сферы игр политических акторов. Только специальное и целенаправленное противодействие замыканию - всемерное развитие принципов справедливости и мери- 
тократии, внедрение и поддержание вертикальных социальных лифтов может привести к подавлению (но не искоренению) этой тенденции.

В сущности, во всех рассмотренных сценариях подобные задачи ставили только «реставраторы», руководимые стремлением воспроизвести кадровую политику КПСС.

Вернемся к сценарию «либерализации». Поскольку «либерализаторам» не удалось решительно расширить представительство партии власти в элите, то совокупная доля криминала, бизнеса и оппозиции убывала крайне медленно: 1996 г. - 67 \%, 2001 г. - 60 \%, 2019 г. - 40 \%. Конечно, «либерализаторы» могли рассчитывать на нейтралитет «родственников», на стойкую поддержку «демпартийцев» и на ситуационные союзы с бизнесом, тем не менее в течение большей части изучаемого периода системные провластные силы оставались в меньшинстве.

Как и «реставраторы», «либерализаторы» не сняли ни одной из предпосылок, породивших политику вертикализации власти в реалистичном сценарии.

Почему провалилась главная надежда «либерализаторов» - продвижение в элиту функционеров и сторонников партии власти? Почему доля «демпартийцев» не росла сколько-либо значительно? Дело в том, что за позиции в элите конкурировали многие силы, сумевшие создать действенные механизмы рекрутирования в элиту своих представителей. Эта конкурентная среда была естественным порождением социальных и экономических трансформаций, которые создали новые силы и толкали эти силы во власть. Элита в такой конкурентной системе не была уже «глиной в руках» федерального центра. Сама по себе власть не была способна рассадить в кресла неких «правильных людей»: для радикального смены облика элиты требовалась трансформация акторов и системы отношений между ними. В сущности, только в реалистичном сценарии прослеживаются шаги в духе подобного социального редизайна.

\section{ЗАКЛЮЧЕНИЕ}

Объективные проблемы, которые создавали угрозы власти и поэтому двигали политику федерального центра в отношении региональных административно-политических элит, были, конечно, одинаковыми во всех рассмотренных сценариях. Это три предпосылки, три мотива трансформации элит в конце 1990-х - начале 2000-х годов: 
1) снижение лояльности и угроза выхода региональных элит из-под контроля центра;

2) утрата легитимности и соответственно рост отчуждения между элитами и народом (такое отчуждение, естественно, проецировалась и на отношения федеральных властей с народом);

3) снижение качества управления: угроза депрофессионализации и массовой коррупции.

В реалистичном сценарии из всех трех угроз политика «вертикализации» устранила в достаточной мере только одну - угрозу выхода элит из-под контроля центра. Кроме того, активное пополнение элиты силовиками и варягами на современном этапе создает просматриваемую перспективу решения проблемы качества управления. Засилье «родственников» и замыкание элиты не дают возможности говорить о том, что решена проблема легитимности, поскольку элита демонстративно игнорирует принципы справедливости и меритократии. А попытки федерального центра разблокировать вертикальные карьерные лифты пока не дали масштабного эффекта.

Однако обсуждая достижения или неудачи реальной политики, полагаем, необходимо иметь в виду, что рассмотренные альтернативные сценарии не устранили ни одной из трех ключевых угроз.

\section{ПРИЛОЖЕНИЕ 1. УСЛОВИЯ СЦЕНАРИЯ 4.2}

Начиная с 24 такта (включительно) в модель внесены следующие изменения.

1. Горкомы, райкомы, обкомы/рескомы, ЦК КПСС были восстановлены с прежними управленческими функциями в сфере подбора кадров. Влияние этих акторов определено как 70 \% от уровня влияние этих же акторов в последний год существования СССР.

2. Новая партия власти (отличная от КПСС) была ликвидирована.

3. Номенклатурная система была восстановлена. Обком КПСС снизил действенность механизмов наследования до 0,11 для «наслендования 1» и до 0,33 для «наследования 2». Эта величина втрое меньше, чем та, которая установилась в последний год перед разрушением номенклатуры.

4. Обком КПСС сократил поддержку локальных администраций, благоприятствующих механизму «наследования», до 0,32. Эта величина вдвое меньше, чем та, которая установилась в последний год перед разрушением номенклатуры. 
5. Под контролем партии были запущены механизмы отбора и продвижения «по службе» из средних звеньев элиты в высшее звено, а также механизм отбора на административные должности из числа «сотрудников предприятий, организаций и учреждений».

6. Через механизмы «выбытие из элиты 1» и «выбытие из элиты 2» во второй половине 1996- первой половине 1997 г. федеральный центр сбросил 10 \% численности всех звеньев (в течение каждого полугодия).

7. Федеральный центр аннулировал поддержку силовиков, что привело к сокращению их влияния на все акторы и механизмы.

8. В начале 2000-х годов силовики не перешли к политике сокращения властных полномочий администрации и к борьбе с неформальными кланами, в связи с чем не были ликвидированы механизмы продажи должностей представителям криминала.

9. В начале 2000-х годов не произошло ослабления пропускной способности выборных механизмов при формировании элиты.

\section{ПРИЛОЖЕНИЕ 2. УСЛОВИЯ СЦЕНАРИЯ 4.3}

Начиная с 24 такта (включительно) в модель внесены следующие изменения.

1. Максимальная (теоретически возможная) пропускная способность механизма выборов повысилась на $20 \%$ - до 12 человек в год.

2. Федеральный центр аннулировал поддержку силовиков, что привело к сокращению их влияния на все акторы и механизмы.

3. В начале 2000-х годов силовики не перешли к политике сокращения властных полномочий администрации и к борьбе с неформальными кланами, в связи с чем не были ликвидированы механизмы продажи должностей представителям криминала.

4. Поддержка региональных организаций партии власти со стороны центральных органов партии власти была увеличена вдвое. Собственный вес региональной организации партии власти возрос вдвое (по сравнению с первой половиной 1996 г.). Все это привело к возрастанию влияния региональных партийных органов на механизмы и иных акторов.

5. Под руководством партии власти был запущен механизм «отбор 4» (рекрутирование кадров из внеэлитной среды на низовые должности в управленческом аппарате) со второй половины 1997 г. (величина эффективности этого механизма совпадает с величиной 2019 г. в реалистичном сценарии). 
6. Пропускная способность механизма «вхождение в элиту через партию власти» была увеличена на 50\%.

\section{Финансирование}

Исследование выполнено при финансовой поддержке РФФИ и ЭИСИ в рамках научного проекта № 20-011-31122 опн «Альтернативные сценарии прошлого, настоящего и будущего: системно-динамическое моделирование политической трансформации региональных элит (Россия, 1991-2035 гг.)».

\section{Литература}

Ахременко А.С. Динамический подход к математическому моделированию политической стабильности // Полис. Политические исследования. 2009. № 3. C. $105-112$.

Бъстрова А.С., Даугавет А.Б., Дука А.В., Колесник Н.В., Невский А.В., Тев Д.Б. Институционализация политической элиты: источники рекрутирования и карьера // Власть и элиты. 2019. Т. 6, № 2. С. 24-66.

Быстрова А.С., Даугавет А.Б., Дука А.В., Тев Д.Б. Региональные властные группы: основные социально-структурные характеристики и роль в развитии современного российского общества // Власть и элиты. 2017. Т. 4. С. 147-169.

Гаман-Голутвина О.B. Метафизические измерения трансформаций российских элит // Политическая концептология. 2012. № 3. С. 38-53.

Гаман-Голутвина О.В. Политические элиты России: вехи исторической эволюцию. М.: РОССПЭН, 2006. 448 с.

Гараедаги Дж. Системное мышление. Как управлять хаосом и сложными процессами: платформа для моделирования архитектуры бизнеса. Минск: Гревцов Букс, 2010. 480 c.

Даугавет А.Б., Дука А.В., Тев Д.Б. Региональные властные группы: основные социально-структурные характеристики и инновационный потенциал // Власть и элиты. 2016. Т. 3. С. 121-186.

Дука А.В. Власть между традиционностью и современностью (элиты российской периферии) // Власть и элиты. 2014. Т. 1. С. 399-436.

Жуков Д.С., Сельиер Д.Г., Барабаш Н.С. Системно-динамическая модель воспроизводства региональных элит в СССР и России // Инноватика и экспертиза: научные труды. 2020. № 1. С. 90-102.

Жуков Д.С., Сельиер Д.Г. Системная динамика российской региональной элиты (1985 - 2019 гг.): альтернативные сценарии // Журнал политических исследований. 2019a. Т. 3, № 4. С. 40-74. URL: https://naukaru.ru/ru/storage/ download/44074.

Жуков Д.С., Сельиер Д.Г. Трансформация региональной административнополитической элиты России: результаты компьютерных экспериментов с системно-динамической моделью // Социально-гуманитарные знания. 2019b. № 8 . C. 7-16. 
Лапина Н.Ю. Региональные элиты: процессы формирования и механизмы взаимодействия в современном российском обществе: автореф. дис. ... д-ра полит. наук. М., 2004. 39 с.

Магомедов А.К. Политическая элита и политическая идеология: рождение символически-смысловой системы регионализма в постсоветской России. Ульяновск: Изд-во Ульяновского госуниверситета, 2018. 246 с.

Магомедов А.К. Мистерия регионализма: региональные правящие элиты и региональные идеологии в современной России: модели политического воссоздания «снизу» (сравнительный анализ на примере республик и областей Поволжья). М.: МОНФ, 2000. 224 с.

Медоуз Д. Азбука системного мышления. М.: Бином; Лаборатория знаний, 2011. 343 c.

Мохов В.П. Эволюция региональной политической элиты России (19501990 гг.). Пермь: ПГТУ, 1998. 256 с.

Мохов В.П. Элитизм и история. Проблемы изучения советских региональных элит. Пермь: ПГТУ, 2000. 204 с.

Нечаев В.Д. Децентрализация, демократизация и эффективность. Реформа федеративных отношений и местного самоуправления через призму теории эффективной децентрализации // Полис. Политические исследования. 2003. № 3. С. 92-101.

Сельцер Д.Г. Взлеты и падения номенклатуры. Тамбов: ОГУП «Тамбовполиграфиздат», 2006. 592 с.

Сельиер Д.Г. Рекрутирование локальной административной элиты России: исходные данные для построения системно-динамической модели // Pro nunc. Современные политические процессы. 2017. № 2. С. 27-32.

Сельиер Д.Г. Центр-периферийные отношения в России (1991-2018 гг.): контуры модели // Социально-гуманитарные знания. 2018. № 8. С. 8-15.

Сельиер Д.Г., Жуков Д.С. Рекрутирование региональной административнополитической элиты России, 1990-2017 гг.: подходы к построению системнодинамической модели // Журнал политических исследований. 2017. Т. 1, № 4. C. 78-101. URL: https://riorpub.com/ru/nauka/article/19598/view (дата обращения: 09.12.2019).

Сельиер Д.Г., Жуков Д.С. Элементы системно-динамической модели рекрутирования региональных административно-политических элит // Российская элитология: инновационные ответы на вызовы современного мира / под ред. А.Ю. Шутов. Ростов н/Д.: ЮРИУФ РАНХиГС, 2019. С. 282-287.

Федорченко С.Н. Государственная кадровая политика в Советском Союзе и современной России: политико-философский анализ. М.: Научно-издательский центр ИНФРА-М, 2017. 154 с.

Форрестер Дж. Мировая динамика. М.: Наука, 1978. 168 с.

Чирикова А.Е., Ледяев В.Г. Власть в малом российском городе. М.: Издательский дом НИУ ВШЭ, 2017. 414 с. 
Чирикова А.Е., Ледяев В.Г., Сельиер Д.Г. Власть в малом российском городе: конфигурация и взаимодействие основных акторов // Полис. Политические исследования. 2014. № 2. С. 88-105.

Armenia S., Carlini C., Onori R., Saullo A.P. Policy modeling as a new area for research: perspectives for a systems thinking and system dynamics approach? // $2^{\text {nd }}$ International Symposium "Systems Thinking for a Sustainable Economy. Advancements in Economic and Managerial Theory and Practice". Roma: Universitas Mercatorum, 2014. P. 1-22.

Axelrod R. Modeling Security Issues of Central Asia. Ann Arbor: University of Michigan, 2004. 23 p.

Choucri N., Goldsmith D., Madnick S., Mistree D., Morrison, J. B., Siegel M. Using system dynamics to model and better understand state stability // MIT Sloan Research Paper. 2007. № 4661-07. P. 1-42. URL: https://ssrn.com/abstract=1011230.

Gilbert N., Ahrweiler P., Barbrook-Johnson P., Narasimhan K.P., Wilkinson H. Computational modelling of public policy: Reflections on practice // Journal of Artificial Societies and Social Simulation. 2018. Vol. 21, issue 1. P. 14. DOI: 10.18564/ jasss.3669. URL: http://jasss.soc.surrey.ac.uk/21/1/14.html.

Ledyaev V., Chirickova A., Seltser D. Who governs? Power in the local Russian community // Journal of Political Power. 2014. Vol. 7, issue 2. P. 211-231.

Ledyaev V.G., Chirikova A.E. Governors and local elites in Russia: patterns of interaction // European politics and society. 2019a. Vol. 20, issue 3. P. 315-332.

Ledyaev V.G., Chirikova A.E. Urban regimes in small Russian towns // City \& Community. 2019b. Vol. 18, issue 3. P. 812-833.

Ledyaev V.G., Chirikova A. Power in local Russian communities: patterns of interaction between legislative and executive branches of local government // Urban Affairs Review. 2017. Vol. 53, issue 6. P. 990-1024.

Ledyaev V., Chirikova A. Business in the power structure of small Russian towns // Europe-Asia Studies. 2020. T. 72, № 4. P. 686-711.

Sharafutdinova G., Turovsky $R$. The politics of federal transfers in Putin's Russia: Regional competition, lobbying, and federal priorities // Post-Soviet Affairs. 2017. Vol. 33, issue 2. P. 161-175.

Sorci P. Measuring the impact of a state's legal and organizational framework on social capital through system dynamics modeling // Rangsit Journal of Social Sciences and Humanities. 2015. Vol. 2, issue 2. P. 49-65.

Turovsky R., Gaivoronsky Y. Russia's regions as winners and losers: Political motives and outcomes in the distribution of federal government transfers // European Politics and Society. 2017. Vol. 18, № 4. P. 529-551. 


\title{
THE BIFURCATION OF 1996 AND RUSSIAN REGIONAL ELITES: HYPOTHETICAL SCENARIOS OF TRANSFORMATION
}

\author{
D. Zhukov, D. Seltser ${ }^{1}$
}

\author{
Derzhavin Tambov State University, \\ Tambov, Russia
}

Citation: Zhukov D., Seltser D. "Razvilka” 1996 goda i rossiyskiye regional'nyye elity: gipoteticheskiye stsenarii transformatsii [The bifurcation of 1996 and Russian regional elites: hypothetical scenarios of transformation]. Vlast' $i$ elity [Power and Elites], 2020, 7 (1): 46-75. (In Russian)

DOI: https://doi.org/10.31119/pe.2020.7.1.3

Annotation. The authors presented alternative scenarios for the development of Russian regional administrative and political elites. These scenarios were generated using the system dynamic model, which is implemented in Powersim Studio. Chronological scope of the study: 1985-2019. The model includes mechanisms, actors and channels for recruiting elites. Object details are formalized in a stock and flow diagram. The model makes it possible to simulate the replenishment of elites by people from different social environments and the dynamics of the composition of the elites. The authors analyzed a realistic scenario and two counterfactual scenarios. Alternative scenarios started in 1996, when other forces came to power after the hypothetical resignation of B. Yeltsin due to deteriorating health. Computer experiments showed that the communist "restoration" and rapid "liberalization" did not eliminate the objective prerequisites for the regional policy that V.V. Putin implemented later.

Keywords: system dynamics simulation, political science, administrative and political elite, regions of Russia, post-Soviet period.

\section{References}

Akhremenko A.S. Dinamicheskiy podkhod k matematicheskomu modelirovaniyu politicheskoy stabil'nosti [A dynamic approach to mathematical modeling of political stability]. Polis. Politicheskie issledovaniya [Polis. Political Studies], 2009, 3, pp. 105-112. (In Russian)

Armenia S., Carlini C., Onori R., Saullo A. P. Policy modeling as a new area for research: perspectives for a systems thinking and system dynamics approach? $2^{\text {nd }}$ International Symposium "Systems Thinking for a Sustainable Economy. Advancements

${ }^{1}$ Corresponding author. E-mail: seltser@yandex.ru. 
in Economic and Managerial Theory and Practice". Roma, Universitas Mercatorum Publ., 2014, pp. 1-22.

Axelrod R. Modeling Security Issues of Central Asia. Ann Arbor, University of Michigan Publ., 2004. 23 p.

Bystrova A.S., Daugavet A.B., Duka A.V., Kolesnik N.V., Nevskiy A.V., Tev D.B. Institutsionalizatsiya politicheskoy elity: istochniki rekrutirovaniya i kar'yera [Institutionalization of the political elite: sources of recruitment and career]. Vlast' $i$ elity [Power and elites], 2019, 6 (2), pp. 24-66. (In Russian)

Bystrova A.S., Daugavet A.B., Duka A.V., Tev D.B. Regional'nyye vlastnyye gruppy: osnovnyye sotsial'no-strukturnyye kharakteristiki i rol' $v$ razvitii sovremennogo rossiyskogo obshchestva [Regional power groups: main social and structural characteristics and role in the development of modern Russian society]. Vlast' $i$ elity [Power and elites], 2017, 4, pp. 147-169. (In Russian)

Chirikova A.E., Ledyaev V.G. Vlast'v malom rossiyskom gorode [Power in a small Russian city]. Moscow: HSE Publishing House, 2017. 414 p. (In Russian)

Chirikova A.E., Ledyaev V.G., Seltser D.G. Vlast' v malom rossiyskom gorode: konfiguratsiya i vzaimodeystvie osnovnykh aktorovPredposylki i osnovnye etapy detsentralizatsii gosudarstvennoy vlasti v Rossii [Power in a small Russian city: configuration and interaction of major actors]. Polis. Politicheskie issledovaniya [Polis. Political Studies], 2014, 2, pp. 88-105. (In Russian)

Choucri N., Goldsmith D., Madnick S., Mistree D., Morrison, J. B., Siegel M. Using system dynamics to model and better understand state stability. MIT Sloan Research Paper, 2007, issue 4661-07, pp. 1-42. Available at: https://ssrn.com/abstract $=1011230$ (accessed: 02 April 2019).

Daugavet A.B., Duka A.V., Tev D.B. Regional'nyye vlastnyye gruppy: osnovnyye sotsial'no-strukturnyye kharakteristiki i innovatsionnyy potentsial. Vlast' $i$ elity [Power and elites], 2016, 3, pp. 121-186. (In Russian)

Duka A.V. Vlast' mezhdu traditsionnost'yu i sovremennost'yu (elity rossiyskoy periferii). Vlast' i elity [Power and elites], 2014, 1, pp. 399-436. (In Russian)

Fedorchenko S.N. Gosudarstvennaya kadrovaya politika $v$ Sovetskom Soyuze i sovremennoy Rossii: politiko-filosofskiy analiz [State personnel policy in the Soviet Union and modern Russia: political and philosophical analysis]. Moscow: Research and Publishing Center INFRA-M Publ., 2017. 154 p. (In Russian)

Forrester J. Mirovaya dinamika [World dynamics]. Moscow: Science Publ., 1978. 168 p. (In Russian)

Gaman-Golutvina O.V. Metafizicheskie izmereniya transformatsiy rossiyskikh elit [Metaphysical measurements of transformations of Russian elites]. Politicheskaya kontseptologiya [Political Conceptology], 2012, 3, pp. 38-53. (In Russian)

Gaman-Golutvina O.V. Politicheskie elity Rossii: vekhi istoricheskoy evolyutsiyu. [Political Elites of Russia: Milestones in Historical Evolution]. Moscow: ROSSPEN Publ., 2006. 448 p. (In Russian) 
Gharajedaghi J. Sistemnoe myshlenie. Kak upravlyat' khaosom i slozhnymi protsessami: Platforma dlya modelirovaniya arkhitektury biznesa [Systems Thinking: Managing Chaos and Complexity: A Platform for Designing Business Architecture]. Minsk: Grevtsov Books Publ., 2010. 480 p. (In Russian)

Lapina N.Y. Regional'nyye elity: protsessy formirovaniya i mekhanizmy vzaimodeystviya $v$ sovremennom rossiyskom obshchestve: avtoreferat dis. ...doktora politicheskikh nauk [Regional elites: processes of formation and mechanisms of interaction in modern Russian society: abstract of dis. ... doctor of political science]. Moscow, 2004. 39 p. (In Russian)

Ledyaev V., Chirickova A., Seltser D. Who governs? Power in the local Russian community. Journal of Political Power, 2014, 7 (2), pp. 211-231.

Ledyaev V., Chirikova A. Business in the power structure of small Russian towns. Europe-Asia Studies, 2020, 72 (4), pp. 686-711.

Ledyaev V.G., Chirikova A. Power in local Russian communities: patterns of interaction between legislative and executive branches of local government. Urban Affairs Review, 2017, 53 (6), pp. 990-1024.

Ledyaev V.G., Chirikova A.E. Governors and local elites in Russia: patterns of interaction. European politics and society, 2019, 20 (3), pp. 315-332.

Ledyaev V.G., Chirikova A.E. Urban regimes in small Russian towns. City \& Community, 2019, 18 (3), pp. 812-833.

Magomedov A.K. Misteriya regionalizma: regional'nyye pravyashchiye elity $i$ regional'nyye ideologii v sovremennoy Rossii: modeli politicheskogo vossozdaniya «snizu» (sravnitel'nyy analiz na primere respublik i oblastey Povolzhya) [Mystery of regionalism: regional ruling elites and regional ideologies in modern Russia: models of political reconstruction "from below" (comparative analysis on the example of the republics and regions of the Volga region)]. Moscow: MONF, 2000. 224 p. (In Russian)

Magomedov A.K. Politicheskaya elita i politicheskaya ideologiya: rozhdeniye simvolicheski-smyslovoy sistemy regionalizma $v$ postsovetskoy Rossii [Political elite and political ideology: the birth of a symbolic-semantic system of regionalism in postSoviet Russia]. Ulyanovsk: Publishing House of the Ulyanovsk State University, 2018. 246 p. (In Russian)

Meadows D. Azbuka sistemnogo myshleniya [Thinking in Systems: A Primer]. Moscow: Laboratory of Knowledge Publ., 2011. 343 p. (In Russian)

Mokhov V.P. Elitizm i istoriya. Problemy izucheniya sovetskikh regional'nykh elit [Elitism and history. Problems of studying Soviet regional elites]. Perm': PSTU Publ., 2000. 204 p. (In Russian)

Mokhov V.P. Evolyutsiya regional'noy politicheskoy elity Rossii (1950-1990 gg.) [The evolution of the regional political elite of Russia (1950-1990)]. Perm: PSTU Publ., 1998. 256 p. (In Russian)

Nechaev V.D. Detsentralizatsiya, demokratizatsiya i effektivnost'. Reforma federativnykh otnosheniy i mestnogo samoupravleniya cherez prizmu teorii effektivnoy 
detsentralizatsii [Decentralization, democratization and efficiency. Reform of federal relations and local self-government through the prism of the theory of effective decentralization]. Polis. Politicheskie issledovaniya [Polis. Political Studies], 2003, 3, pp. 92-101. (In Russian)

Seltser D.G. Rekrutirovanie lokal'noy administrativnoy elity Rossii: iskhodnye dannye dlya postroeniya sistemno-dinamicheskoy modeli [Recruiting the local administrative elite of Russia: initial data for building a system-dynamic model]. Pro nunc. Sovremennye politicheskie protsessy [Pro nunc. Modern political processes], 2017, 2, pp. 27-32. (In Russian)

Seltser D.G. Tsentr-periferiynye otnosheniya v Rossii (1991-2018 gg.): kontury modeli [Center-peripheral relations in Russia (1991-2018): model outlines]. Sotsial'no-gumanitarnye znaniya [Social and Humanitarian Knowledge], 2018, 8, pp. 8-15. (In Russian)

Seltser D.G. Vzlety i padeniya nomenklatury [The ups and downs of the nomenclature]. Tambov: OGUP Tambovpolygraphizdat Publ., 2006. 592 p. (In Russian)

Seltser D.G., Zhukov D.S. Elementy sistemno-dinamicheskoy modeli rekrutirovaniya regional'nykh administrativno-politicheskikh elit [Elements of a systemdynamic model of recruiting regional administrative and political elites]. Rossiyskaya elitologiya: innovatsionnye otvety na vyzovy sovremennogo mira [Russian elite studies: innovative answers to the challenges of the modern world]. Rostov-on-Don: YURIUF RANEPA Publ., 2019, pp. 282-287. (In Russian)

Seltser D.G., Zhukov D.S. Rekrutirovanie regional'noy administrativno-politicheskoy elity Rossii, 1990-2017 gg.: podkhody k postroeniyu sistemno-dinamicheskoy modeli [Recruiting the regional administrative and political elite of Russia, 19902017: approaches to building a system-dynamic model]. Zhurnal politicheskikh issledovaniy [Journal of Policy Studies], 2017, 1 (4), pp. 78-101. Available at: https:// riorpub.com/ru/nauka/article/19598/view. (In Russian)

Sharafutdinova G., Turovsky R. The politics of federal transfers in Putin's Russia: Regional competition, lobbying, and federal priorities. Post-Soviet Affairs, 2017, 33 (2), pp. 161-175.

Sorci P. Measuring the impact of a state's legal and organizational framework on social capital through system dynamics modeling. Rangsit Journal Of Social Sciences And Humanities, 2015, 2 (2), pp. 49-65.

Turovsky R., Gaivoronsky Y. Russia's regions as winners and losers: Political motives and outcomes in the distribution of federal government transfers. European Politics and Society, 2017, 18 (4), pp. 529-551.

Zhukov D.S., Seltser D.G., Barabash N.S. Sistemno-dinamicheskaya model' vosproizvodstva regional'nykh elit v SSSR i Rossii [System dynamic model of reproduction of regional elites in the USSR and Russia]. Innovatika i ekspertiza: nauchnyye trudy [Innovation and Expertise: Research Publications], 2020, 1, pp. 90-102. (In Russian) 
Zhukov D.S., Seltser D.G. Sistemnaya dinamika rossiyskoy regional'noy elity (1985-2019 gg.): al'ternativnyye stsenarii [System dynamics of the Russian regional elite (1985 - 2019): alternative scenarios]. Zhurnal politicheskikh issledovaniy [Journal of Policy Studies], 2019, 4, pp. 40-74. (In Russian)

Zhukov D.S., Seltser D.G. Transformatsiya regional'noy administrativnopoliticheskoy elity Rossii: rezul'taty komp'yuternykh eksperimentov s sistemnodinamicheskoy model'yu [Transformation of Russia's regional administrative and political elite: Results of computer experiments with a system-dynamic model]. Sotsial'no-gumanitarnye znaniya [Social and Humanitarian Knowledge], 2019, 8, pp. 7-16. (In Russian) 